\title{
Herbage productivity and ungulate use of northeastern Nevada mountain meadows
}

\author{
JEFFREY L. BECK AND JAMES M. PEEK
}

At the time of the research authors were Graduate Research Assistant and Professor, Department of Fish and Wildlife Resources, University of Idaho, Moscow, Idaho, 83844-1136.

\section{Abstract}

The effects of grazing by cattle (Bos taurus) and recently reestablished elk (Cervus elaphus) on mountain meadows in northeastern Nevada are poorly understood. We evaluated production, use, and species richness of herbage standing crop in and outside 3 meadow exclosures in northeastern Nevada's Jarbidge Mountains across 3 seasons in 1999 and 2000. Treatments included control, wildlife (mainly big game), and cattle. There was less forb standing crop in fall than in early or midsummer, but no difference in forb standing crop from early to mid-summer across all treatments. There were no differences in graminoid standing crop among treatments in 1999, while there was significantly less graminoid crop in cattle treatments in $\mathbf{2 0 0 0}$ than in the control or wildlife treatments. Species lists in exclosures and cattle treatments overlapped 48.9-68.4\%. Clipping treatments to evaluate effects of use on yearly productivity were light use (13.3-24.7\%) and total use (clipped to ground) in early and mid-summer, and control. There was no difference in fall or graminoid herbage between controls and quadrats clipped lightly in early summer and mid-summer and there was no difference in forb or graminoid yield (seasonally clipped herbage plus end of growing season herbage) in clipped quadrats and controls. Across years, forbs and graminoids clipped to ground in early summer and mid-summer regrew by fall to no more than 19.2, 4.2, 24.7, and $10.0 \%$, respectively, of the amount in control quadrats. Managers should consider delaying cattle grazing until late summer on mountain meadows used consistently by elk in early summer.

Key Words: elk, cattle, Cervus elaphus, clipping treatments, compensation, grazing exclosures, meadow production, species richness, utilization

USDA Humboldt-Toiyabe National Forest (HTNF), Rocky Mountain Elk Foundation, Nevada Bighorns Unlimited, Elko Bighorns Unlimited, USDI Bureau of Land Management, National Fish and Wildlife Foundation, Safari Club International, the College of Natural Resources, and the Cooperative Fish and Wildlife Research Unit, University of Idaho supported our research. In particular, we thank the Nevada Division of Wildlife for supplying fencing materials. K. Smolski, J. Lewis, L. Peterson, C. Rudeen, D. King, and R. McGinty were invaluable field assistants. A. Dean, C. Howell, C. Jean, and C. Olson, HTNF, conducted ecological site analyses. D. Aicher, J. Frederick, F. Frampton, M. McNeill, and J. Speck, from HTNF; and B. Brackett, C. Brackett, and R. Brewer from 71 Livestock Association assisted in meaningful ways. $\mathrm{K}$. Launchbaugh reviewed an earlier manuscript. R. Steinhorst and C. Williams provided statistical advice. S. Brunsfeld, College of Natural Resources Herbarium, University of Idaho, verified plant voucher specimens.

Manuscript accepted 16 Oct. 03.

\section{Resumen}

Los efectos del apacentamiento del ganado (Bos taurus) y del recientemente restablecido alce (Cervus elaphus) en las praderas montañosas del noreste de Nevada son pobremente entendidos. Durante 3 estaciones, de 1999 a 2000, evaluamos la producción, la riqueza de especies y el uso de la biomasa de forraje en pie dentro y fuera de 3 exclusiones en praderas de las montañas Jarbidge en el noreste de Nevada. Los tratamientos incluyeron el control, fauna silvestre (principalmente fauna mayor) y ganado. Hubo menos biomasa de hierbas en otoño que a inicios o mediados del verano, pero de inicio a mediados del verano no hubo diferencia entre tratamientos en la biomasa en pie de las hierbas. En 1999 no hubo diferencias entre tratamientos en la biomasa en pie de las gramíneas, mientras que en el 2000 hubo significativamente menos biomasa de gramíneas en el tratamiento de ganado que en el control o en el de fauna silvestre. Las listas de especies en las exclusiones y el tratamiento de ganado se traslaparon entre 48.9 a $68.4 \%$. Los tratamientos de corte para evaluar los efectos del uso en la productividad anual fueron: uso ligero ( $13.3-24.7 \%$ ) y uso total (cortado al ras del suelo) a inicios y mediados del verano y el control. No hubo diferencias en la biomasa de las gramíneas de otoño entre el control y los cuadrantes cortados ligeramente a inicios y mediados de otoño y no hubo diferencia en el rendimiento de biomasa de hierbas o gramíneas (el forraje cortado estacionalmete mas el forraje del final de la estación) entre los cuadrantes cortados y el control. A través de los años las hierbas y gramíneas cortadas a ras del suelo a inicios y mediados de verano rebrotaron en otoño pero no mas de 19.2, 4.2, 24.7 y $10.0 \%$ respectivamente de la cantidad registrada en los cuadrantes control. En las praderas de montaña utilizadas consistentemente por el alce a inicios de verano los manejadores deben considerar el retrasar el apacentamiento del ganado hasta fines del verano.

Mountain meadows occur on about $1,618,800$ ha $(\sim 50 \%$ private and $\sim 50 \%$ public lands) across the western United States (Gomm 1979). Where available, they provide an extremely productive, nutritious, and reliable forage resource (Reid and Pickford 1946, Patton and Judd 1970). For example, moist mountain meadows on forested summer range in eastern Oregon and eastern Washington comprise only $1-2 \%$ of the area, however, they may produce upwards of $20 \%$ of summer range forage (Reid and Pickford 1946). Wet mountain meadows are typically flooded in spring and are therefore dominated by flood-tolerant graminoids and to a lesser extent by a variety of forbs (mostly non-legumes), and a few phreatophytic shrubs (Cooper et al. 1957, Gomm 
1979). As summer progresses, cattle (Bos taurus) are drawn to mountain meadows where forage quality is sustained longer than in surrounding communities (Reid and Pickford 1946). Higher quality forage persists because mountain meadows are either subirrigated by springs (wet meadows) or fed by melting snow (dry meadows). Consequently, calves, yearlings, and adult cattle grazing meadows have demonstrated higher weight gains than cattle grazing adjacent upland areas (Cooper et al. 1957, Clanton and Burzlaff 1966).

Elk (Cervus elaphus) rely heavily on mountain meadows in many areas for spring and early summer forage (Kowalsky 1964, Hayden-Wing 1979, Mantz 1993, Kelly 1995). Elk have recently been reestablished and (or) are colonizing the mountain ranges of northeastern Nevada (Nevada Division of Wildlife 1997). Concern has been expressed over impacts of these new elk populations grazing mountain meadows because meadows are a major source of cattle forage in Nevada (Hackett 1984).

Herbaceous mountain meadows interspersed among mountain big sagebrush (Artemisia tridentata ssp. vaseyana [Rydb.] Beetle) and low sagebrush ( $A$. arbuscula Nutt.) communities in northeastern Nevada provide forage throughout summer to livestock and wildlife including elk, mule deer (Odocoileus hemionus), pronghorn (Antilocapra americana), whitetailed jackrabbit (Lepus americanus), ground squirrels (Spermophilus spp.), and greater sage-grouse (Centrocercus urophasianus). Livestock grazing has been the dominant summer use of northeastern Nevada mountain rangelands since cattle ranching began following the Civil War (Timothy 1980, Young and Evans 1989, Gruell 1998). Mountain meadows in the region were commonly hayed to provide winter cattle forage (Young and Evans 1989, Gruell 1998). Cattle, domestic sheep, and horses owned by local producers competed for summer forage with large, out-of-state sheep bands in the late 1800 s and early 1900s (Timothy 1980 , Young and Evans 1989, Gruell 1998). Grazing practices have largely healed early grazing abuses since designation of mountain rangelands as National Forest Reserves in the early 1900s (Timothy 1980, Gruell 1998).

We examined annual productivity and use of mountain meadows by wildlife (mainly big game) and cattle in and adjacent to meadow exclosures in northeastern Nevada. Our primary objectives were to evaluate: (1) production, use by cattle and wild ungulates, and species richness of herbaceous standing crop in meadow communities during early summer, mid-summer, and fall, 1999 and 2000, and (2) end of growing season (fall 1999 and 2000) meadow production and annual yield from plants clipped to light use levels (13.3-24.7\%), total use (clipped to ground, or $100 \%$ ), and protected from all grazing during early summer and midsummer.

\section{Materials and Methods}

\section{Study Area}

Our 166,500 ha study area was located in northeastern Elko County, Nevada (Fig. 1). The Humboldt-Toiyabe National Forest (HTNF), Jarbidge Ranger District comprised 94,226 ha $(56.6 \%)$, Bureau of Land Management $35.9 \%$, and private lands $7.5 \%$ of the study area. Elevation ranges from 1,633 to $3,287 \mathrm{~m}$. Soils across the study area are formed from igneous parent material (rhyolite and basalt; USDA Forest Service 1981, Manning and Padgett 1995). The northern slope of the Jarbidge Mountains drains into the Snake River, while south slopes drain into the Great Basin. Deposition of rhyolitic boulders in high elevation glacial cirques has rendered subalpine sites porous and droughty (Loope 1969, Manning and Padgett 1995), consequently, most meadows occur at lower elevations.

Snowpack accumulated from late fall through mid-spring provides most moisture. Snow water equivalents on 1 April at Natural Resources Conservation Service SNOTEL sites at Pole Creek Ranger Station $(2,540 \mathrm{~m})$ in the north and near the meadow communities, and Draw Creek $(2,300 \mathrm{~m})$ in the south, were 91 and $90 \%$, and 88 and $104 \%$ of 30 -year (1971-2000) averages (Draw Creek, $297 \mathrm{~mm}$; Pole Creek, $523 \mathrm{~mm}$ ) in 1999 and 2000, respectively. Mean monthly temperatures $\left({ }^{\circ} \mathrm{C}\right)$ averaged from June through October were $11.3 \pm 2.1$ in 1999 and $13.6 \pm 2.0$ in 2000 at Draw Creek, and $9.6 \pm 2.4$ in 1999 and $11.4 \pm 2.0$ in 2000 at Pole Creek Ranger Station. June through October cumulative precipitation was 104 and $41 \mathrm{~mm}$, and 101 and $51 \mathrm{~mm}$, in 1999 and 2000 at Draw Creek and Pole Creek Ranger Station, respectively.

Elk were reintroduced into the Jarbidge Mountains from 1990-95 (Nevada Division of Wildlife 1997) and a population of about 300 (density $=0.18 \mathrm{~km}^{-2}$ ) was maintained by antlerless harvest from 1996-2000 (Beck 2003). Elk shared sum- mer range with mule deer, pronghorn, cattle, and domestic sheep (Ovis aries). Principal land use was summer and early fall grazing on 1 common use, 11 domestic sheep, and 33 cattle allotments.

Mountain big sagebrush and low sagebrush interspersed with herbaceous meadows and snowbank associations form a matrix between forested summer range communities including aspen (Populus tremuloides Michaux), curlleaf mountain mahogany (Cercocarpus ledifolius Nutt.), snowbrush (Ceanothus velutinus Dougl. ex Hook.), and conifer consisting primarily of subalpine fir (Abies lasiocarpa [Hook.] Nutt.), limber pine (Pinus flexilis James), and whitebark pine ( $P$. albicaulis Engelm.). Vegetation coverage from Nevada GAP, a geographical database (Scott et al. 1993), indicated mountain meadow communities comprised $\leq 0.2 \%$ of the area.

We evaluated 3 meadow communities, Black Spring, Monument Spring, and a meadow community north of Sagehen Spring, hereafter Sagehen Spring, that were partially fenced with $1.07-\mathrm{m}$ high, 4strand barbwire fences to exclude spring water sources from cattle (Fig. 1). Springs were piped to provide water in troughs outside spring exclosures. The fence around Monument Spring was erected in 1994, and fences apparently were built around Black and Sagehen Springs in the 1980s (J. Speck, HTNF, Wells Nev., personal communication 2003). Livestock and wildlife grazed these areas before fence placement, and wild herbivores currently graze areas inside the exclosures as well as in the adjacent unfenced areas. Forest Service personnel evaluated these meadow complexes during the course of our study to assess vegetation and soil water conditions (Weixelman et al. 1996).

Black Spring. Black Spring ( $41^{\circ} 52.8^{\prime}$ $\mathrm{N}, 115^{\circ} 7.6^{\prime} \mathrm{W} ; 2,246 \mathrm{~m}$ elevation; $\mathrm{E}$ aspect; $4.4 \%$ slope) is located in the HTNF Black Spring cattle allotment. Black Spring and Caudle Creek allotments $(5,271 \mathrm{ha})$ were managed under a deferred rotation grazing system and stocked with cow/calf pairs at a rate of $0.82 \mathrm{AUM} \mathrm{ha}^{-1}$ from 6 July through 11 October 1999 , and $0.72 \mathrm{AUM} \mathrm{ha}^{-1}$ from 1 July through 16 September 2000 . The cattle exclosure encompassed 0.3 ha around Black Spring. The meadow community at Black Spring was classified as a mesic graminoid/Aquic Cryoboroll/trough drainageway ecological type (Weixelman et al. 1996).

Common forbs included Chamisso arnica (Arnica chamissonis Less.), common dandelion (Taraxacum officinale G.H. 

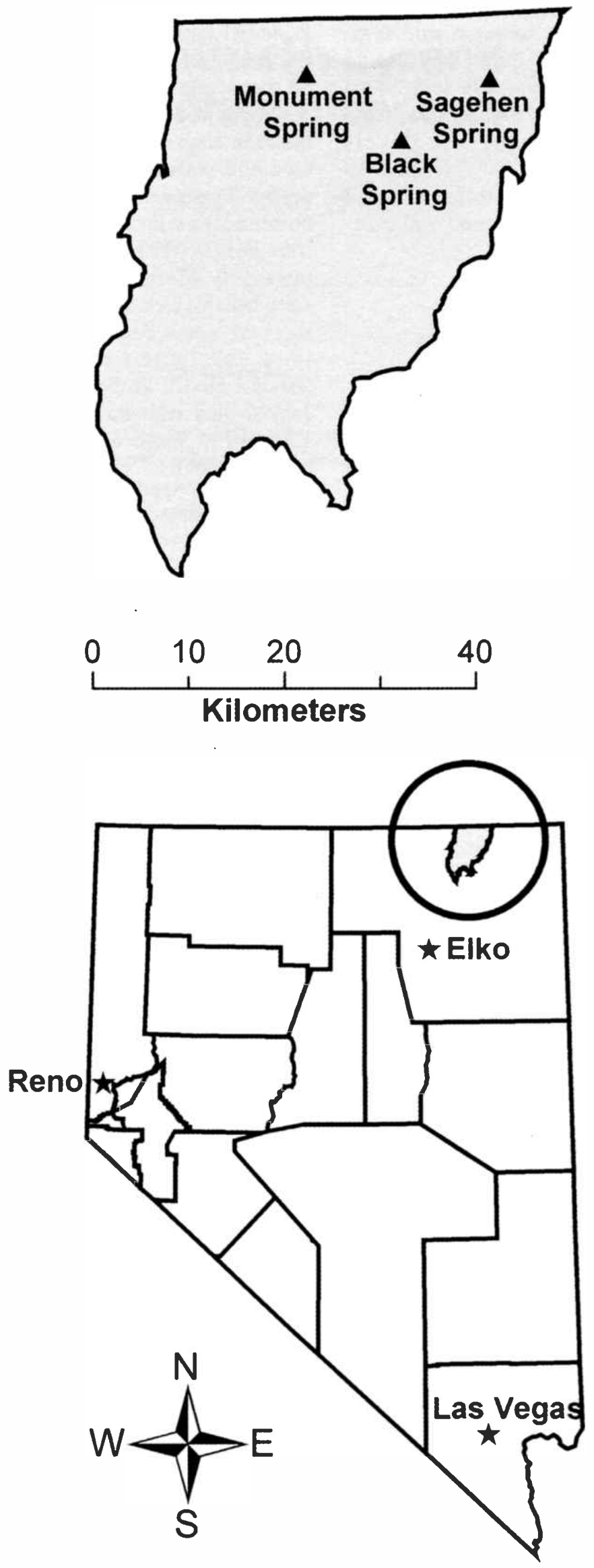

Fig. 1. Location of mountain meadow communities, Jarbidge Mountains, Nev. The study area encompassed the 166,500 ha Nevada Division of Wildlife Hunt Unit 072.
Weber ex Wiggers), common yarrow (Achillea millefolium L.), fringed willowherb (Epilobium ciliatum Raf.), lambstongue ragwort (Senecio integerrimus Nutt.), largeleaf avens (Geum macrophyllum Willd.), longleaf starwort (Stellaria longifolia Muhl. ex Willd.), pleated gentian (Gentiana affinis Griseb.), slender cinquefoil (Potentilla gracilis Dougl. ex. Hook.), thistle (Cirsium spp. P. Mill.), and western aster (Symphyotrichum ascendens [Lindl.] Nesom). Common graminoids included Baltic rush (Juncus balticus Willd.), Columbia needlegrass (Achnatherum nelsonii [Scribn.] Barkworth), Douglas' sedge (Carex douglasii Boott), Kentucky bluegrass (Poa pratensis $\mathrm{L}$.), many-ribbed sedge ( $C$. multicostata Mack.), meadow barley (Hordeum brachyantherum Nevski), Nebraska sedge (C. nebrascensis Dewey), redtop (Agrostis gigantea Roth), and tufted hairgrass (Deschampsia caespitosa [L.] Beauv.). Black Spring meadow community was assessed to be moderately similar to its potential natural community with $43 \%$ of species moderately similar and $28 \%$ of species highly similar to the potential natural community (C. Howell, HTNF, Wells Nev., personal communication 2001).

Monument Spring. Monument Spring $\left(41^{\circ} 56.7^{\prime} \mathrm{N}, 115^{\circ} 14.7^{\prime} \mathrm{W} ; 2,094\right.$ m elevation; aspect NE; $4.4 \%$ slope) is located in the HTNF Spring Creek cattle allotment. Spring Creek allotment (3,083 ha) was managed under a 3-pasture rest rotation grazing system and stocked with cow/calf pairs at a rate of approximately $1.40 \mathrm{AUM} \mathrm{ha}^{-1}$ from 1 July through 15 October 1999 and 2000. The grazing unit in which Monument Spring was located was grazed both years. The cattle exclosure encompassed 2.5 ha around a spring. A buck and pole fence comprised the northeast exclosure corner. The meadow community at Monument Spring was classified as a dry graminoid/Cryoboroll/trough drainageway ecological type (Weixelman et al. 1996).

Common forbs included common yarrow, common dandelion, field pennycress (Thlaspi arvense L.), longleaf starwort, mountain deathcamas (Zigadenus elegans Pursh), pale agoseris (Agoseris glauca Pursh [Raf.]), Rocky Mountain iris (Iris missouriensis Nutt.), slender cinquefoil, western aster, and yellow evening-primrose (Oenothera flava A. Nels.). Common graminoids included Baltic rush, Kentucky bluegrass, many-ribbed sedge, meadow barley, prairie junegrass (Koeleria macran. tha [Ledeb.] J.A. Schultes), slender wheatgrass (Elymus trachycaulus (Link) Gould ex Shinners), streambank wheatgrass $(E$. 
lanceolatus Scribn. \& J.G. Sm.), and timothy (Phleum pratense L.). Monument Spring meadow community had very low similarity to the potential natural community with no high similarity species, and $37 \%$ and $63 \%$ of species, respectively, expressed moderate and low similarity to the potential natural community (C. Jean, HTNF, Wells, Nev., personal communication 1999).

Sagehen Spring. Sagehen Spring $\left(41^{\circ}\right.$ $56.2^{\prime} \mathrm{N}, 115^{\circ} 0.8^{\prime} \mathrm{W} ; 2,017 \mathrm{~m}$ elevation; $\mathrm{NE}$ aspect; $5.0 \%$ slope) is located in the HTNF Wilson Creek cattle allotment. Wilson Creek allotment $(2,434$ ha) was managed under a 3-pasture deferred rotation grazing system and stocked with cow/calf pairs at a rate of $0.70 \mathrm{AUM} \mathrm{ha}^{-1}$ from 1 July through 30 September 1999 , and $0.66 \mathrm{AUM} \mathrm{ha}^{-1}$ from 7 July through 30 September 2000. The cattle exclosure encompassed 0.7 ha around a spring. Sagehen Spring meadow community was a mesic graminoid/Aquic Cryoboroll/trough drainageway ecological type (Weixelman et al. 1996).

Common forbs included Chamisso arni$\mathrm{ca}$, common dandelion, Idaho blue-eyed grass (Sisyrinchium idahoense Bickn.), longleaf starwort, Oregon checkerbloom (Sidalcea oregana [Nutt. ex Torr. \& Gray] Gray), pleated gentian, Rocky Mountain iris, rosy pussytoes (Antennaria rosea Greene), Rydberg's penstemon (Penstemon rydbergii A. Nels.), slender cinquefoil, thistle, and western aster. Common graminoids included Baltic rush, clustered field sedge ( $C$. praegracilis W. Boott), Douglas' sedge, Kentucky bluegrass, Mat muhly (Muhlenbergia richardsonis (Trin.) Rydb.), prairie junegrass, redtop, slender wheatgrass, and tufted hairgrass. Sagehen Spring meadow community was moderately similar to the potential natural community with $32 \%$ of species moderately and $38 \%$ of species highly similar to the potential natural community (C. Jean, HTNF, Wells, Nev., personal communication 1999).

\section{Exclosure Experimental Design}

Our experimental design was a randomized complete block with repeated measures for 2 years (1999 and 2000) over 3 seasons: (1) before cattle entry (early summer, mid- to late June); (2) peak production (mid-summer, early to mid-August); and (3) end of growing season (fall) production following cattle removal (late September to mid-October). The randomized block with 3 blocks and 3 treatments served as the whole plot and 3 seasons sampled over 2 years were the repeated measures (split plot). Therefore, tests for whole plot factors have fewer degrees of freedom than tests involving time factors. A 3-way grazing exclosure was constructed in each meadow community (blocks) in fall 1998 by adding a woven wire ungulate-proof exclosure to the existing cattleproof exclosure (Fig. 1). Each 3-way exclosure consisted of an ungulate-proof exclosure (control) and 2 treatments (wildlife use only, and combined cattle and wildlife use). In fall 1998 we clipped 10 random $0.1-\mathrm{m}^{2}(20 \times 50 \mathrm{~cm})$ quadrats to $5 \mathrm{~cm}$ in paired $225-\mathrm{m}^{2}$ areas inside and outside the cattle-proof exclosures at Monument and Sagehen Springs to evaluate utilization. We did not consider Black Spring in fall 1998 use estimates as cattle had grazed inside this exclosure in summer. We found mean herbaceous dry matter (DM [ $\left.0.1 \mathrm{~m}^{-2}\right]$ ) was 94.0 and $93.2 \%$ lower in the combined use area compared to the exclosure (grazed by wildlife only) at Monument and Sagehen Springs, respectively. Tracks and fecal pats indicated use was primarily attributable to cattle, thus we designated the combined use treatment as the cattle treatment.

The woven wire ungulate-proof exclosures, $2.5-\mathrm{m}$ high $\times 15.3 \mathrm{~m} \times 15.3 \mathrm{~m}$, provided protection from ungulate use within a 234- $\mathrm{m}^{2}$ area. A $225-\mathrm{m}^{2}$ plot was established within each ungulate exclosure (control). A 225- $\mathrm{m}^{2}$ plot outside the ungulate-proof exclosure, but inside the cattle exclosure provided access to big game while restricting cattle use (wildlife treatment). A 225$\mathrm{m}^{2}$ plot was selected outside the exclosure to evaluate use by cattle and wildlife (cattle treatment). At each sampling occasion, a grid was established in each $225-\mathrm{m}^{2}$ plot to facilitate placement of sampling quadrats. Grids consisted of 10 perpendicular lines spaced $1.5 \mathrm{~m}$ apart along a $15.24-\mathrm{m}$ center baseline. Ten locations for sampling quadrats were spaced in $1.5 \mathrm{~m}$ intervals along each of these lines for a total of 100 possible sampling locations.

All ANOVAs were analyzed with Statistical Analysis System software (SAS; PROC GLM; SAS Institute Inc. 2001). Outlier observations were removed (no more than 2 most extreme to approach balance) if they had a large influence on model variance as detected in residual $x$ predicted plots, and appropriate transformations of treatment responses were conducted if responses did not meet assumptions of statistical tests (Oehlert 2000). Highest order non-significant interaction terms in ANOVA models were pooled into sampling error. Estimated treatment response least squares means were back- transformed (Fowler et al. 1998). Standard errors associated with transformed least squares means were approximated to their original scale according to the delta method (Bishop et al. 1975). Reported treatment estimates are accordingly backtransformed lsmeans $\pm 1 \mathrm{SE}$. We conducted post hoc multiple comparisons with the Tukey-Kramer HSD test. Statistical significance was set at $\alpha=0.05$.

\section{Productivity, Use, and Species Rich- ness of Herbage}

We ocularly estimated standing crop (g) for each species within 15 randomly selected, $0.1-\mathrm{m}^{2}(20 \times 50 \mathrm{~cm})$ sampling quadrats at each $225-\mathrm{m}^{2}$-treatment plot during each sampling period. We used double sampling to estimate herbage mass by forage class (forbs and graminoids) within $0.1-\mathrm{m}^{2}$ quadrats (Bonham 1989). Shrubs were a very minor component and were not considered in these analyses. Standing crop of forbs and graminoids (grasses, sedges, and rushes) was estimated in all 15 quadrats and standing crop in 3 quadrats in the wildlife and cattle treatments and 5 quadrats in controls were clipped to ground level and separated and weighed (Interagency Technical Reference 1996). Fresh weights were recorded to the nearest $0.5 \mathrm{~g}$ and samples weighing less than $0.5 \mathrm{~g}$ (traces) were recorded as $0.1 \mathrm{~g}$.

Linear regressions using estimated fresh weights as independent variables and clipped weights as dependent variables (PROC REG; SAS Institute Inc. 2001) by forage class in $0.1-\mathrm{m}^{2}$ quadrats at each meadow location in each sampling period were used to calibrate estimates of fresh standing crop in quadrats that were not clipped. Clipped samples were placed in paper bags and initially air-dried to prevent degradation, then oven dried in a forced-air oven at $60^{\circ} \mathrm{C}$ for 24 hours and weighed to $\pm 0.01 \mathrm{~g}$. Mean \%DM from clipped quadrats in the same treatments was multiplied by calibrated estimates of fresh herbage in estimated quadrats to calculate $\mathrm{g} \mathrm{DM} \mathrm{m}^{-2}$ for ocularly estimated quadrats. Average $\mathrm{g} \mathrm{DM} \mathrm{m}^{-2}$ was calculated at each location from $\mathrm{g} D \mathrm{DM}$ in all 15 , $0.1-\mathrm{m}^{2}$ quadrats.

We evaluated end of growing season use at each meadow. Total fall herbage (forbs plus graminoids) estimated at each control served as the comparison to total fall herbage estimated in wildlife and cattle treatments. Percent use was thus calculated as the difference in mean $\mathrm{g} \mathrm{DM} \mathrm{m}^{-2}$ between the control and each treatment in fall (i.e., $\%$ use $=[$ (control $g-$ treatment 
g)/control g] x 100). Herbaceous species richness in $0.1-\mathrm{m}^{2}$ sampling quadrats was pooled in each treatment across seasons and years and was further pooled among the control and wildlife treatment to calculate exclosure richness.

\section{Clipping Treatments Experimental Design}

We clipped 5 random $0.1-\mathrm{m}^{2}$ quadrats inside big game exclosures in early summer (mid- to late June) and mid-summer (early to mid-August) 1999 and 2000 to simulate light use (mean \% fresh clipped weight removed $0.1-\mathrm{m}^{-2}=13.3-24.7 \%$ ) on annual production. Elk feeding site analyses in sagebrush and meadow communities in our study area indicated very light use of perennial forbs $(9.1 \pm 1.8 \% ; \bar{x} \pm$ $\mathrm{SE})$ and perennial graminoids ( $1.3 \pm 0.3 \%$; Beck 2003) similar to elk use levels $(1.8-13.7 \%)$ reported by Hayden-Wing (1979) for total meadow production in central Idaho mountain meadows. Our clipping levels were higher than these elk use levels. In addition, the 5 quadrats previously clipped to ground level in the big game exclosure during early summer and mid-summer 1999 and 2000 to evaluate standing crop were used to compare herbage regrowth following total defoliation. All clipped quadrats were marked with flagged wire to facilitate placement of $0.1-\mathrm{m}^{2}$ quadrats in fall.

Our experimental design was a split plot. The whole plot was a randomized complete block with 3 blocks (exclosures) and 5 treatments: (1) light use in June (early summer light use); (2) clipped to ground in June (early summer total use); (3) light use in August (mid-summer light use); (4) clipped to ground in August (mid-summer total use); and (5) annual above-ground production with no use (control). The split plot factor was measurements repeated over 2 years.

We evaluated above ground annual yield (seasonally clipped herbage plus end of growing season herbage; Kowalsky 1964 , Kelly 1995) in $0.1-\mathrm{m}^{2}$ quadrats clipped in early and mid-summer at light use and total use levels. Yield provided us a measure as to whether herbage compensated for defoliation treatments. We compared end of growing season yield (g DM $\mathrm{m}^{-2}$ ) in clipped quadrats to annual herbage production in controls. This experimental design was a split plot with randomized complete block whole plot ( 3 blocks and 5 treatments) and split plot factor being repeated measures over 2 years.

\section{Results}

\section{Productivity, Use, and Species \\ Richness of Herbage}

There were no differences in forb standing crop among treatments or between years. There was a significant difference in forb standing crop among seasons $\left(F_{2,33}=22.41, P<0.001\right)$. There was less forb standing crop in fall than in early summer or mid-summer, but no difference in forb standing crop from early summer to mid-summer across all treatments. Significant differences were detected in forb standing crop for season $x$ year $\left(\mathrm{F}_{2,33}\right.$ $=14.52, \mathrm{P}<0.001)$, treatment $\mathrm{x}$ year $\left(F_{2,33}=5.06, P=0.012\right)$, and treatment $x$ season $\left(F_{4,33}=3.90, P=0.011\right)$ interactions. Forb standing crop (mean $\mathrm{g} \mathrm{DM} \mathrm{m}^{-2}$ ) was nearly twice as high in early summer $2000(37.1 \pm 3.7 \mathrm{~g})$ as in early summer $1999(19.8 \pm 2.7 \mathrm{~g})$, but was essentially the same by fall (Fig. 2A). Forb standing crop was $59.9 \%$ higher in wildlife treatments and $4.6 \%$ in controls, but was $39.5 \%$ less in cattle treatments from 1999 to 2000 (Table 1). Forbs decreased from early summer through fall in all treatments, but decreased significantly more in cattle treatments (Fig. 2B). Forb standing crop in cattle treatments did not differ from forb standing crop in wildlife treatments in 1999, but was less in 2000 (Table 1).

There was no difference in graminoid standing crop among treatments, seasons, or for the season $\mathrm{x}$ year interaction. Mean graminoid standing crop (g DM m ${ }^{-2}$ ) across all treatments was $40.1 \%$ higher in $1999(138.7 \pm 12.2)$ than in $2000(99.0 \pm$ $\left.8.7 ; F_{1,32}=7.25, P=0.011\right)$. There were significant differences between treatment $x$ year $\left(F_{2,32}=3.80, P=0.033\right)$ and treatment $x$ season $\left(F_{4,32}=5.00, P=0.003\right)$ interaction terms. Graminoid standing crop was $3.1 \%$ higher in wildlife treatments, and 21.6 and $55.0 \%$ less in controls and cattle treatments, respectively, from 1999 to 2000 (Table 1). From early summer through fall, graminoid standing crop generally increased in controls, increased from early summer to mid-summer and then stabilized through fall in wildlife treatments, and decreased in cattle treatments from mid-summer to fall (Fig. 2C). There were no significant differences in graminoid standing crop among treatments in 1999, while there was significantly less graminoid standing crop in cattle treatments in 2000 than in the control or wildlife treatments (Table 1).

In 1999, we observed use in the wildlife treatments at Black Spring (elk, pronghorn, and greater sage-grouse) and
Table 1. Mountain meadow treatment $\mathrm{x}$ year graminoid and forb standing crop (g DM m ${ }^{-2}$; Ismean \pm SE), Jarbidge Mountains, Nev., 1999 and 2000. Standing crop estimates are averaged across seasons and within years.

\begin{tabular}{lcc}
\hline \hline Treatment & Forbs & Graminoids \\
\hline & $-\cdots---\cdot-\cdot\left(\mathrm{g} \mathrm{DM} \mathrm{m}^{-2}\right)$--------- \\
1999 & & \\
Control & $26.2 \pm 3.1^{\mathrm{A}}$ & $171.4 \pm 27.5^{\mathrm{A}}$ \\
Cattle & $18.5 \pm 2.8^{\mathrm{AB}}$ & $126.0 \pm 20.3^{\mathrm{A}}$ \\
Wildlife & $14.2 \pm 2.3^{\mathrm{BC}}$ & $123.6 \pm 19.9^{\mathrm{A}}$ \\
2000 & & \\
Control & $27.4 \pm 3.2^{\mathrm{A}}$ & $134.4 \pm 19.9^{\mathrm{A}}$ \\
Cattle & $11.2 \pm 2.0^{\mathrm{B}}$ & $56.7 \pm 9.1^{\mathrm{B}}$ \\
Wildlife & $22.7 \pm 2.9^{\mathrm{AC}}$ & $127.4 \pm 20.5^{\mathrm{A}}$ \\
\hline
\end{tabular}

\begin{abstract}
${ }_{\mathrm{ABC}}$ Estimates in the same column followed by the same superscript are not significantly different $(P>0.05)$ as tested by Tukey-Kramer HSD tests.
\end{abstract}

Monument Spring (pronghorn); no wildlife use was detected at Sagehen Spring. We detected elk (Black Spring), pronghorn (Monument Spring), and rabbit (white-tailed jackrabbits and [or] mountain cottontail [Sylvilagus nuttallii]; Sagehen Spring) use in wildlife treatments in 2000. In 1999 and 2000 we detected cattle use at each meadow location by August. Cattle use was very light $(<5 \%)$ in mid-summer at some meadows due to grazing allotment rotations, but increased to fall. Cattle use of total herbage was higher in 2000 than in 1999 (Table 2). Mean percent use of total herbage after cattle removal in fall in cattle treatments was 2.2-times higher in 1999 and 4.5times higher in 2000 than in wildlife treatments (Table 2).

Herbaceous species richness was 35 in both the Black Spring exclosure (21 forbs, 9 grasses, 2 rushes, and 3 carices) and in the cattle treatment (18 forbs, 13 grasses, 2 rushes, and 2 carices). The exclosure and cattle treatment both shared $65.7 \%$ of the same species (i.e., percentage of species identified in the exclosure and also identified in the cattle treatment and vice versa). Total species list overlap at the Black Spring exclosure and adjacent cattle treat-

Table 2. Percent use of total herbage (forbs and graminoids) in mountain meadows by cattle and wildlife, Jarbidge Mountains, Nev., fall 1999 and 2000. Reported are mean differences $\left( \pm 1 \mathrm{SE} \%\right.$ ) in $\mathrm{g} \mathrm{DM} \mathrm{m} \mathrm{m}^{-2}$ between controls and cattle and wildlife treatments in fall.

\begin{tabular}{llc}
\hline \hline & \multicolumn{1}{c}{1999} & 2000 \\
\hline Cattle & $-0.8 \pm 23.2$ & $64.6 \pm 24.5$ \\
Wildlife & $19.5 \pm 1.1$ & $14.4 \pm 15.4^{1}$ \\
\hline
\end{tabular}

${ }^{1}$ This estimate reflects $11.9 \%$ more herbage in the wildlife treatment than in the control at Monument Spring in fall 2000. 

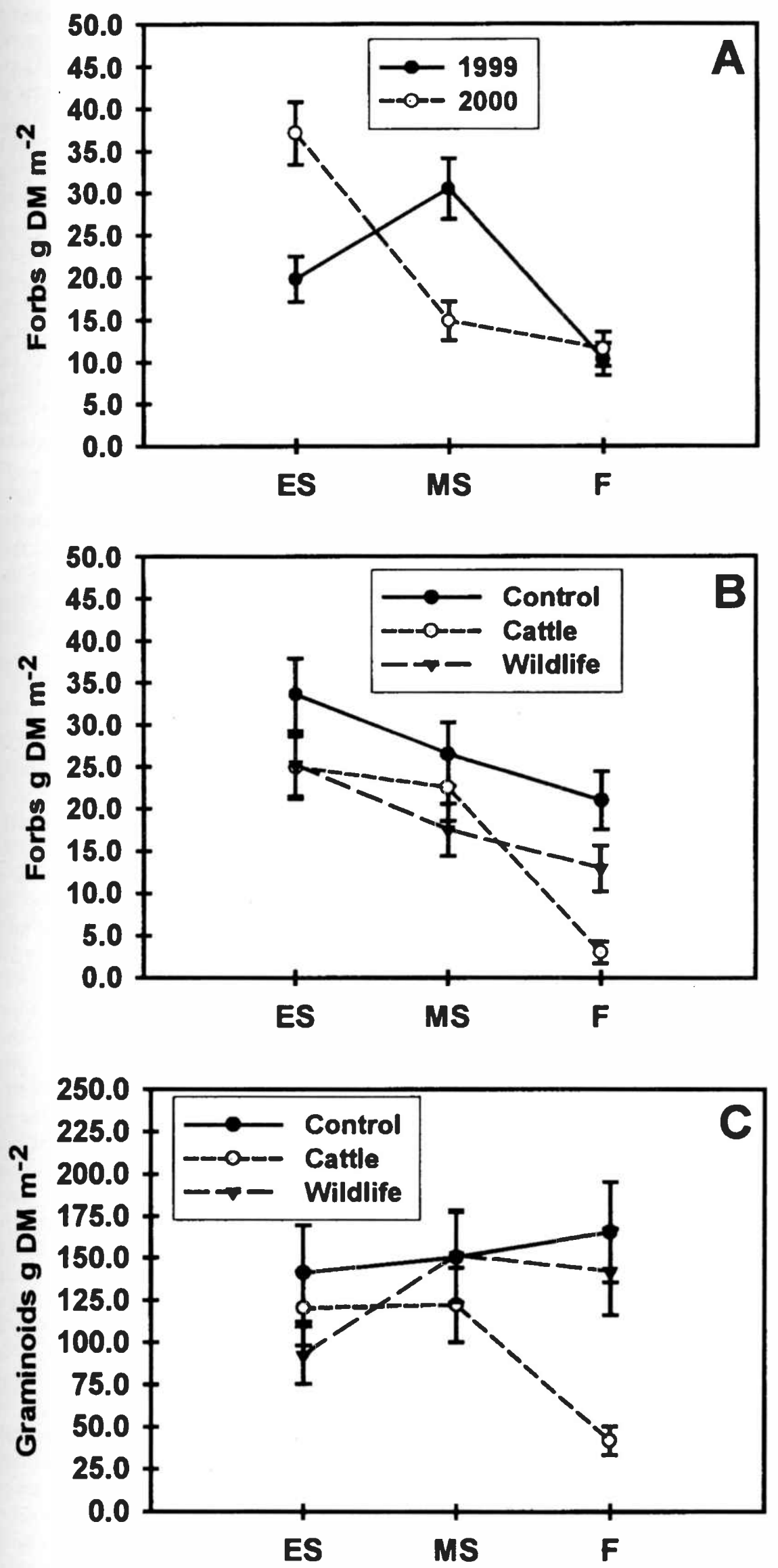

Fig. 2. Mountain meadow standing crop $\left(\mathrm{g} \mathrm{DM} \mathrm{m}^{-2}\right.$; lsmean $\left.\pm \mathrm{SE}\right)$ of $(\mathrm{A})$ forbs, year $\mathrm{x}$ season across all treatments, $(B)$ forbs, treatment $x$ season, across years, and $(C)$ graminoids, treatment $x$ season, across years. Seasons are early summer (ES), mid-summer (MS), and fall (F) and years are 1999 and 2000. ment was 23 of 47 species $(48.9 \%)$. Monument Spring exclosure herbaceous species richness was 37 ( 23 forbs, 11 grasses, 1 rush, and 2 carices) and 32 (19 forbs, 9 grasses, 1 rush, and 3 carices) in the cattle treatment. The exclosure shared $62.2 \%$ of species found in the cattle treatment, while $71.9 \%$ of the species in the cattle treatment were also found in the exclosure. Total species list overlap at the Monument Spring exclosure and adjacent cattle treatment was 23 of 46 species $(50.0 \%)$. Sagehen Spring herbaceous species richness was 33 ( 22 forbs, 8 grasses, 1 rush, and 2 carices) in the exclosure and 31 ( 20 forbs, 7 grasses, 1 rush, and 3 carices) in the cattle treatment. The exclosure shared $78.8 \%$ of species found in the cattle treatment, while $83.9 \%$ of the species in the cattle treatment were also found in the exclosure. Total species list overlap at the Sagehen Spring exclosure and adjacent cattle treatment was 26 of 38 species $(68.4 \%)$.

\section{Clipping Treatments}

There was a significant difference for forb $\left(\mathrm{F}_{4.8}=15.56, \mathrm{P}<0.001\right)$ and graminoid $\left(\mathrm{F}_{4.8}=21.78, \mathrm{P}<0.001\right) \mathrm{g} \mathrm{DM}$ $\mathrm{m}^{-2}$ among clipping treatments. Forb and graminoid production in quadrats lightly clipped in early summer and mid-summer did not differ from 1999 or 2000 control quadrat production (Table 3). Yearly forb production in quadrats clipped to ground in mid-summer was significantly less than forbs clipped to ground in early summer. Fall graminoid production in quadrats clipped to ground in early summer did not differ from production in quadrats clipped to ground in mid-summer 1999 and 2000, respectively (Table 3 ).

Mean $\mathrm{g} \mathrm{DM} \mathrm{m}^{-2}$ was higher across all treatments in 1999 (forbs, $9.4 \pm 0.9$; graminoids, $113.0 \pm 7.3$ ) than in 2000 (forbs, $6.6 \pm 0.6$; graminoids, $83.3 \pm 6.3$ ) for forbs $\left(F_{1,10}=6.96, P=0.025\right)$ and graminoids $\left(\mathrm{F}_{1,10}=9.31, \mathrm{P}=0.012\right)$. There was a significant treatment $x$ year interaction for forbs $\left(F_{4,10}=10.64, P=\right.$ $0.001)$ and graminoids $\left(\mathrm{F}_{4,10}=3.65, \mathrm{P}=\right.$ 0.044). Forbs and graminoids clipped to ground level in early summer and midsummer regrew by fall on average (mean for 1999 and 2000) to no more than 19.2 , $4.2,24.7$, and $10.0 \%$, respectively, of the amount in control quadrats. Forb and graminoid yield in clipped quadrats did not differ from annual fall $\mathrm{g} \mathrm{DM} \mathrm{m}^{-2}$ in control quadrats among treatments or years. 
Table 3. Mountain meadow forb and graminoid response $\left(\mathrm{g} \mathrm{DM} \mathrm{m}^{-2}\right.$; Ismean $\left.\pm \mathrm{SE}\right)$ in fall to clipping treatments, Jarbidge Mountains, Nev., 1999 and 2000.

\begin{tabular}{lcc}
\hline \hline Treatment & Forbs & Graminoids \\
\hline & & \\
1999 & $24.3 \pm 5.2^{\mathrm{A}}$ & $167.9 \pm 20.2^{\mathrm{A}}$ \\
Control $^{\mathrm{A}}$ & $13.2 \pm 2.8^{\mathrm{A}}$ & $174.8 \pm 20.7^{\mathrm{A}}$ \\
Early summer light use $^{2}$ & $9.1 \pm 1.9^{\mathrm{AC}}$ & $80.2 \pm 14.0^{\mathrm{AB}}$ \\
Early summer total use $^{3}$ & $9.9 \pm 2.1^{\mathrm{A}}$ & $165.5 \pm 20.1^{\mathrm{A}}$ \\
Mid-summer light use $^{\mathrm{B}}$ & $2.6 \pm 0.5^{\mathrm{B}}$ & $26.6 \pm 8.1^{\mathrm{BC}}$ \\
Mid-summer total use & & \\
& & \\
2000 & $27.8 \pm 6.0^{\mathrm{A}}$ & $172.8 \pm 20.5^{\mathrm{A}}$ \\
Control & $16.5 \pm 3.6^{\mathrm{A}}$ & $174.0 \pm 20.6^{\mathrm{A}}$ \\
Early summer light use & $2.8 \pm 0.6^{\mathrm{BC}}$ & $16.1 \pm 6.3^{\mathrm{C}}$ \\
Early summer total use & $19.4 \pm 4.2^{\mathrm{A}}$ & $147.9 \pm 19.0^{\mathrm{A}}$ \\
Mid-summer light use & $0.5 \pm 0.1^{\mathrm{D}}$ & $9.7 \pm 4.9^{\mathrm{C}}$ \\
Mid-summer total use &
\end{tabular}

${ }^{C}$ Controls represent yearly herbage production in unclipped quadrats clipped to ground in fall.

${ }^{2}$ Light use quadrats were clipped to remove $13.3-24.7 \%$ of herbage at each defoliation event.

${ }^{3}$ Total use quadrats were clipped to ground level.

${ }^{A B C D}$ Estimates in the same column followed by the same superscript are not significantly different $(P>0.05)$ as tested by Tukey-Kramer HSD tests.

\section{Discussion}

\section{Productivity, Use, and Species Richness of Herbage}

Recent work in Montana suggests exclosures need to be larger than 4 ha in size to facilitate equal elk presence inside and adjacent to exclosures (Gross and Knight 2000). Comparisons of elk and cattle use around exclosures could thus be biased, as elk may not be willing to cross fences to access smaller exclosures (Gross and Knight 2000). However, our smallest exclosure (Black Spring, 0.3 ha) was the only exclosure where we documented elk use. Elk in our study area appeared to be willing to cross fences to access limited meadow forage.

Fall use in cattle treatments was very high on 3 occasions (Black Spring 1999, $83.6 \%$; Black Spring 2000, 94.5\%; Monument Spring 2000, 83.3\%). Although 1 April snow water equivalents at the Pole Creek Administrative Site were $470 \mathrm{~mm}$ in 1999 and $467 \mathrm{~mm}$ in 2000 , early summer warming coupled with strong winds and a $49.5 \%$ reduction in June-October cumulative precipitation in 2000 apparently reduced herbage productivity and stimulated earlier phenological development of herbs in communities across the study area. Weather patterns reducing plant productivity likely contributed to higher cattle use levels in 2000 .

Because it is often impossible to enumerate the number of species in a community, we consider the number of species we tabulated for species richness to be an underestimate (Krebs 1999). Forb diversity may increase in areas grazed by cattle in northern Nevada (Clary and Medin 1990); however, we detected 2-4 more forb species in exclosures than in cattle treatments at each meadow community. Graminoid richness comparisons between exclosures and controls were more similar, but showed no consistent patterns. Wildlife and trespass cattle grazing since exclosures were built may have had some affect in increasing or maintaining slightly higher species richness in exclosures. Similarly, Green and Kauffman (1995) found lower richness in dry and wet meadows excluded from grazing for 10 years, compared to the richness of adjacent areas grazed up to $70 \%$ in northeastern Oregon. Similarity indices indicate historical grazing in our study area has altered potential vegetation compositions at meadow complexes (Weixelman et al. 1996). Establishment of exotic grasses such as Kentucky bluegrass and timothy at meadow communities in our study area has likely further deflected compositional development away from potential conditions. Therefore, our species richness comparisons probably reflect responses of different portions of meadow communities to grazing and grazing exclusion following historical grazing and introduction of exotics. Overall, species lists overlapped $48.9-68.4 \%$ at exclosures and cattle treatments at each meadow. By comparison, species lists overlapped $57.9 \pm 2.8 \%$ between long-ungrazed and adjacent plots at 26 long-term Rocky Mountain grassland exclosures in Colorado, Montana, South Dakota, and Wyoming (Stohlgren et al. 1999).

Some have reported that relatively moderate grazing can elevate productivity of many types of grasslands above levels in the absence of grazing (McNaughton 1993, Noy-Meir 1993); however, other researchers indicate plant overcompensa- tion in response to grazing on western rangelands rarely occurs (Painter and Belsky 1993). Evidence suggests cattle grazing can facilitate increased levels of graminoid herbage preferentially selected by sympatric cervids (Gordon 1988). Higher production and survival of red deer (C. elaphus) has been observed in areas on the Isle of Rhum in Scotland grazed by cattle compared to areas not grazed by cattle (Gordon 1988). Some western mountain grasslands have deteriorated where elk grazing follows cattle grazing, suggesting that compensation either is not sufficient to withstand a second grazing activity (Patten 1993) or that overuse rather than compensation, occurs. Furthermore, elk may concurrently forage in summer in areas with cattle or forage completely absent from cattle in rested allotments (Werner and Urness 1998, Halstead et al. 2002), suggesting other factors such as habitat selection are more important than cattle grazing in facilitating elk grazing.

\section{Clipping Treatments}

Timing of use is obviously important, as elk used forbs and grasses in central Idaho mountain meadows most frequently in July, whereas sedges and rushes were used most in June (Hayden-Wing 1979). Our clipping treatments did not indicate forb or graminoid production was affected by light clipping in early summer or midsummer. Compensation did not occur following our clipping treatments in northeastern Nevada mountain meadows where growth and regrowth were most likely promoted by subirrigated soils. Clipping mountain meadow vegetation in central Idaho to $5 \mathrm{~cm}$ in early June to simulate elk use and then again in late June to simulate cattle use resulted in yields similar to cattle-only grazing simulated in late June (Kowalsky 1964). In contrast, clipping to $5 \mathrm{~cm}$ in early June yielded results similar to no grazing (Kowalsky 1964). Likewise, standing crop of tufted hairgrass clipped to $5 \mathrm{~cm}$ to simulate elk use in early June in east central Idaho did not differ from unclipped plants 1 or 2 months after treatment (Kelly 1995). These results suggest that elk use of mountain meadows in early summer has negligible effects on total yearly production of meadow vegetation. However, Kelly (1995) reported yield of tufted hairgrass clipped to simulate elk use in early June and cattle use in early August was lower than clipping treatments to simulate elk use in early June and cattle use in early July. 


\section{Management Implications}

Timing of grazing on mountain meadow forbs is a critical concern. In our study, forb availability declined throughout summer, especially in cattle treatments, and total use clipping treatments in early and mid-summer resulted in low regrowth of forbs. However, where management is intended to reduce cattle use on riparian areas, cattle stocked in early summer (late June) at moderate rates (average of 2.08 AUM ha ${ }^{-1}$ ) tend to graze mountain meadows heavier than nearby riparian areas (Clary and Booth 1993).

The location of mountain meadows will play an important role in their probability of use by wild ungulates. Elk used mountain meadows greatest when they were adjacent to cover and secluded from roads and other human activity in northcentral Idaho (Kowalsky 1964). Elk in eastern Arizona demonstrated selection, though not as pronounced as deer, for nearby forest edge over wet meadow and transition areas (Patton and Judd 1970). Infrequent visits to meadows were probably to obtain meadow food plants containing higher protein levels than plants in drier sites (Patton and Judd 1970). Excessive early season use will dramatically decrease annual herbage production. Managers should identify meadows that receive consistent early summer use by elk and then restrict cattle grazing these meadows to late summer or early fall to avoid impairing productivity of graminoids and especially forbs.

\section{Literature Cited}

Beck, J.L. 2003. Elk summer range habitat, nutritional ecology, and carrying capacity in the Jarbidge Mountains, Nevada. Ph.D. Diss., Univ. Idaho, Moscow, Ida.

Bishop, Y.M.M., S.E. Fienberg, and D.W. Holland. 1975. Discrete multivariate analysis: theory and practice. MIT Press, Cambridge, Mass.

Bonham, C.D. 1989. Measurements for terrestrial vegetation. John Wiley and Sons, New York, N.Y.

Clanton, D.C. and D.F. Burzlaff. 1966. Grazing cattle on sub-irrigated meadows. J. Range Manage. 19:151-152.

Clary, W.P. and G.D. Booth. 1993. Early season utilization of mountain meadow riparian pastures. J. Range Manage. 46:493-497.

Clary, W.P. and D.E. Medin. 1990. Differences in vegetation biomass and structure due to cattle grazing in a northern Nevada riparian ecosystem. USDA For. Serv. Intermountain Res. Sta., Res. Paper INT-427. Ogden, Ut.
Cooper, C.S., R.R.Wheeler, and W.A. Sawyer. 1957. Meadow grazing-1: a comparison of gains of calves and yearlings when summering on native flood meadows and sagebrush-bunchgrass range. J. Range Manage. 10:172-174.

Fowler, J., L. Cohen, and P. Jarvis. 1998. Practical statistics for field biology, $2^{\text {nd }}$ Ed. John Wiley and Sons, Limited. Chichester, West Sussex, England.

Gomm, F.B. 1979. Grazing management on mountain meadows, p. 147-163. In: R.H. Delaney and J. Borrelli (eds.) Proc. Symp. on Management of Intermountain Meadows. Univ. of Wyoming Coll. of Agr. and Colorado State Univ. Mountain Meadow Res. Center. Jackson, Wyo.

Gordon, I.J. 1988. Facilitation of red deer grazing by cattle and its impact on red deer performance. J. Appl. Ecol. 25:1-10.

Green, D.M. and J.B. Kauffman. 1995. Succession and livestock grazing in a northeastern Oregon riparian ecosystem. J. Range Manage. 48:307-313

Gross, J.A. and J.E. Knight. 2000. Elk presence inside various-sized cattle exclosures. J. Range Manage. 53:287-290.

Gruell, G.E. 1998. Northern Elko County: the way it was. Northeastern Nevada Historical Society Quarterly 98-4:105-126.

Hackett, E.I. 1984. Planning a fertilizer program-Nevada suggestions, p. 81-90. In: E.G. Siemer and R.H. Delaney (eds.) Proc. of the Second Intermountain Meadow Symposium. Colorado State Univ. and Univ. of Wyoming Agr. Exp. Stations. Gunnison, Colo.

Halstead, L.E., L.D. Howery, G.B. Ruyle, P.R. Krausman, and R.J. Steidl. 2002. Elk and cattle forage use under a specialized grazing system. J. Range Manage. 55:360-366.

Hayden-Wing, L.D. 1979. Elk use of mountain meadows in the Idaho primitive area, $\mathrm{p}$. 40-46. In: M.S. Boyce and L.D. HaydenWing (eds.) North American elk: ecology, behavior, and management. Univ. Wyoming, Laramie, Wyo.

Interagency Technical Reference. 1996. Sampling vegetation attributes. U. S. Dep. Agric. For. Serv., Nat. Resour. Cons. Serv.: Grazing Lands Tech. Inst., U. S. Dep. Interior, Bur. Land Manage.

Kelly, S.M. 1995. Elk and cattle range relations on the Lemhi Mountains, Idaho. M.S. Thesis, Univ. Wyoming, Laramie, Wyo.

Kowalsky, S.I. 1964. Ecology of mountain meadows and use by elk. M.S. Thesis, Univ. Idaho, Moscow, Ida.

Krebs, C.J. 1999. Ecological methodology, $2^{\text {nd }}$ Ed. Addison Wesley Longman, Inc., Menlo Park, Calif.

Loope, L.L. 1969. Subalpine and alpine vegetation of northeastern Nevada. Ph.D. Diss., Duke Univ., Durham, N.C.

Manning, M.E. and W.G. Padgett. 1995. Riparian community type classification for Humboldt and Toiyabe national forests, Nevada and eastern California. USDA For. Serv. Intermountain Region, R4-Ecol-95-01. Ogden, Ut.
Mantz, G.K. 1993. Spring elk effects on the availability of summer cattle forage in the Uinta Mountains of Utah. M.S. Thesis, Utah State Univ., Logan, Ut.

McNaughton, S.J. 1993. Grasses and grazers, science and management. Ecol. Appl. 3:17-20.

Nevada Division of Wildlife. 1997. Nevada elk species management plan. Nevada Div. Wildl., Reno, Nev.

Noy-Meir, I. 1993. Compensating growth of grazed plants and its relevance to the use of rangelands. Ecol. Appl. 3:32-34.

Oehlert, G.W. 2000. A first course in the design and analysis of experiments. W.H. Freeman and Co., New York, N.Y.

Painter, E.L. and A.J. Belsky. 1993. Application of herbivore optimization theory to rangelands of the western United States. Ecol. Appl. 3:2-9.

Patten, D.T. 1993. Herbivore optimization and overcompensation: does native herbivory on western rangelands support these theories? Ecol. Appl. 3:35-36.

Patton, D.R. and B.I. Judd. 1970. The role of wet meadows as wildlife habitat in the Southwest. J. Range Manage. 23:272-275.

Reid, E.H. and G.D. Pickford. 1946. Judging mountain meadow range condition in eastern Oregon and eastern Washington. U.S. Dept. Agric. Circ. 748. U.S. Government Printing Office, Washington, D.C.

SAS Institute Inc. 2001. SAS/STAT User's Guide, Release 8.2. SAS Institute Inc., Cary, N.C.

Scott, J.M., F. Davis, B. Csuti, R. Noss, B. Butterfield, C. Groves, H. Anderson, S. Caicco, F. D'erchia, T. C. Edwards, Jr., J. Ulliman, and R. G. Wright. 1993. Gap analysis: a geographic approach to protection of biological diversity. Wildl. Monogr. 123.

Stohlgren, T.J., L.D. Schell, and B. Vanden Heuvel. 1999. How grazing and soil quality affect native and exotic plant diversity in Rocky Mountain grasslands. Ecol. Appl. 9:45-64.

Timothy, K. 1980. Jarbidge Ranger District: it can be done. Rangelands 2:160-161.

USDA Forest Service. 1981. Environmental assessment for the release of elk into the Jarbidge Mountains, Elko County, Nevada. USDA For. Serv., Humboldt Nat. For., Elko, Nev.

Weixelman, D.A., D.C. Zamudio, and K.A. Zamudio. 1996. Central Nevada riparian field guide. USDA For. Serv. INT-R4ECOL-96-01. Sparks, Nev.

Werner, S.J. and P.J. Urness. 1998. Elk forage utilization within rested units of restrotation grazing systems. J. Range Manage. 51:14-18.

Young, J.A. and R.A. Evans. 1989. Silver state rangelands-historical perspective. Rangelands 11:199-203. 